\begin{tabular}{|c|c|c|c|}
\hline \multirow{2}{*}{$\begin{array}{c}\text { LARUS } \\
\text { Hrvatska akademija } \\
\text { znanosti i umjetnosti }\end{array}$} & 55 & $\begin{array}{c}7-25 \text { str. } \\
2 \text { tablice, } 5 \text { slika }\end{array}$ & Zagreb 2020. \\
\cline { 2 - 4 } & $(2020)$ & \multicolumn{3}{|c|}{$\begin{array}{c}\text { Primljeno 5.7.2020. } \\
\text { Prihvaćeno od Razreda za prirodne znanosti HAZU 28.11.2020. }\end{array}$} \\
\hline
\end{tabular}

UDK 598.235.72(497.5)

Original scientific paper Izvorni znanstveni članak

DOI: https://dx.doi.org/10.21857/ypn4oc1 kd9

\title{
THE FIRST ANALYSIS OF HEAVY METALS IN THE GREY HERON Ardea cinerea FEATHERS FROM THE CROATIAN COLONIES
}

\section{Proa analiza teških metala u perima sivih čaplji Ardea cinerea iz hrvatskih kolonija}

\section{Dora Bjedov ${ }^{1}$, Alma Mikuška', Mirna Velki ${ }^{1}$, Zdenko Lončarić', TiBOR MIKUŠKA ${ }^{3}$}

${ }^{1}$ Department of Biology, Josip Juraj Strossmayer University of Osijek, Cara Hadrijana 8/A, 31000 Osijek, Croatia

${ }^{2}$ Department of Agroecology and Environment Protection, Faculty of Agrobiotechnical Sciences Osijek, Josip Juraj Strossmayer University of Osijek, Vladimira Preloga 1, 31000 Osijek, Croatia

${ }^{3}$ Croatian Society for Birds and Nature Protection, Ivana Gundulića 19/A, 31000 Osijek, Croatia

\begin{abstract}
This study represents the first analysis of heavy metals: lead and cadmium, as well as two metalloids: arsenic and selenium, in the feathers of Grey Herons breeding in Croatia. The Grey Heron was chosen as a model apex predator of the wetland ecosystem due to high trophic level, feeding habits, long lifespan and abundance. Sampling was conducted during the 2019 breeding season in April and May from six Grey Herons colonies in Croatia (Mrsunjski lug, Kopački rit, Piljenice, Kravarsko, Čepin, Slovinci), whose environment is heavily influenced by rivers Danube, Drava and Sava tributaries. The primary and secondary flight feathers were collected under the colonies as shed feathers or from dead birds. The feathers are a suitable non-invasive method for metal and metalloid analysis, and can reflect internal concentrations, depending on the metal. In the Slovinci colony, we measured the highest lead
\end{abstract}

e-mail: dora.bjedov@gmail.com, amikuska@biologija.unios.hr, mvelki@biologija.unios.hr, zdenko. loncaric@fazos.hr, tibor.kopacki.rit@gmail.com 
$(\mathrm{Pb})$ and cadmium $(\mathrm{Cd})$ concentrations $\left(2194.53 \pm 416.20 \mu \mathrm{g} \mathrm{kg}^{-1} \mathrm{dw}\right.$ and $79.30 \pm 9.37 \mu \mathrm{g} \mathrm{kg}{ }^{-1} \mathrm{dw}$, respectively). The highest arsenic (As) and selenium (Se) concentrations were found in the Čepin colony (359.70 \pm $301.46 \mu \mathrm{g} \mathrm{kg}^{-1} \mathrm{dw}$ and $3375.61 \pm 2502.80 \mu \mathrm{g} \mathrm{kg}^{-1} \mathrm{dw}$, respectively). All the measured levels of heavy metals and metalloids are below concentrations that can cause adverse health effects in birds.

Keywords: biomonitoring, non-invasive sampling, apex predator birds, metal pollution, Croatia

\section{INTRODUCTION}

Increased input of hazardous substances, such as heavy metals, from anthropogenic sources results in environmental pollution that may cause adverse effects on the surrounding fauna and flora (JANSSENs et al. 2001). Metal reactivity depends on their different forms in the environment, and the metal-induced toxicity is related to the oxidative status. Unlike organic compounds, metals cannot be metabolized into less toxic compounds, which results in their high persistence (Koivula \& Eeva 2010). Analysing heavy metal pollution by using living organisms can provide more reliable results compared to only measuring the metal concentration in the environment (MАRкоwsкi et al. 2013). Apex predators have proved to be relevant bioindicators for various xenobiotics, such as heavy metals and persistent organic pollutants (POPs) (Eulaers et al. 2011). Due to rapid accumulation of chemicals in the freshwater ecosystem and accumulation of chemicals in the sediment, waterbirds are particularly at risk (BURGER \& EICHORST 2005), but they can serve as excellent bioindicators of environmental change (KusHLAN 1993). In aquatic environment, existing contaminants can biomagnify through the food chain, reaching deleterious concentrations at the highest trophic levels, and causing adverse health effects on reproduction, egg hatchability, hatching survival, and neurobehavioral development (Tsipoura et al. 2011). Considering all this, in the present study, the Grey Heron Ardea cinerea was chosen as a model apex predator of the wetland ecosystem. The Grey Heron is the most abundant species of the heron family (Ardeidae) in Croatia, with increasing population since the 1970s (MikušKa et al. 2005, Komljenović 2019). It is a long-lived species with estimated 10.3 years generation length (BIRDLife INTERNATIONAL 2020); they can live up to 37 years in the wild (FrAnsson et al. 2010). As a typical wetland bird, it is found in freshwater ecosystems, e.g. rivers, lakes, ponds, wetlands, marshes, water reservoirs (Wiтнеквy et al. 1949), where it feeds on fish, amphibians, crustaceans, snakes, small mammals and large insects (HANCock \& Kushlan 1984). Daily food intake is estimated to be 500 grams of prey per day (DEL Hoyo et al. 1992). Quite often, particularly during drought or winter, when freshwaters are frozen, it would stalk and feed on small rodents on agricultural land, meadows and pastures. Depending on prey abundance, it can forage solitaire or in groups 
next to other freshwater bird species, such as other heron species, gulls, spoonbills, and storks (Jakubas \& Mioduszewska 2005). The breeding colonies, heronries, are usually built close to feeding sites (up to $8 \mathrm{~km}$ ), but birds can forage up to $20 \mathrm{~km}$ from the breeding site (WнітеRв 1943). It is a breeding, migratory and wintering bird species in Croatia. It is however hypothesized that a part of the Croatian population is partially resident (MiKušKa et al. 2005, LuKAČ 2007, KRALJ et al. 2013). Grey Herons in Croatia start to breed earlier than other heron species, in late March and early April. At the time of breeding, sexually immature birds are not present in the colonies. Grey Herons would undergo partial moulting that would not impact their flight capabilities. Partial post-juvenile moult is confined to most of the body feathers and rarely some wing coverts, while the flight feathers remain unmoulted until their second year (Blasco-Zumeta \& Heinze 2020). The adults finish their post-breeding moult usually in November. Herons are very often used as bioindicator for local contaminations due to their abundance, position in the food chain, and exposure to various hazardous chemicals through their diet containing pollutants that have a tendency to bioaccumulate (BURGER 1994, Burger 1995, Scheifler et al. 2006, Burger et al. 2007, Deng et al. 2007, Horai et al. 2007). Feather analysis is an informative indicator for investigating various physiological processes affected by metals. The feathers are suitable monitoring tools for metals and metalloids, especially in top predators, which have a long life span, so that various xenobiotics have time to accumulate (RUткоwsкA et al. 2018). There are at least three different mechanisms for increasing metal concentration in the feather: internal deposition during growth, which reflects internal contamination, contamination by secretions from preen oil gland, and external contamination (GoEde \& De Bruin 1986). The feathers can be collected in a noninvasive way, stored at room temperature, and easily transported (Eulaers et al. 2011). Metal variation in the feather can be attributed to several factors, such as moulting pattern, feather segment, feather formation, rate of feather growth, leaching, pigmentation and external contamination (direct or from preen gland) (Goede \& De Bruin 1984). The feathers are good indicators of exposure to arsenic and lead. Selenium levels in the feathers reflect the internal exposure history of the bird (Goede 1985, Burger 1993, Ansara-Ross et al. 2013). The feathers are furthermore reliable biomonitoring tools for cadmium exposure, as they are correlated with internal concentration in liver, kidney and uropygial gland (Pilastro et al. 1993). Although the Grey Heron feathers have already been used around the world for heavy metal biomonitoring, no such study on the feathers has been completed in Croatia. The main objective of this study is to use the feathers as a non-destructive biomonitoring matrix, and assess the concentrations of heavy metals - lead and cadmium, as well as two metalloids - arsenic and selenium. This study represents the first analysis of metals and metalloids in the feathers of the Grey Heron breeding in Croatia. 


\section{MATERIALS AND METHODS}

The sampling was conducted during the 2019 breeding season in April and May. The feathers were collected under the colonies from six different locations: Mrsunjski lug $(n=4)$, Kopački rit $(n=4)$, Piljenice $(n=3)$, Kravarsko $(n=3)$, Čepin $(n=2)$, and Slovinci $(n=2)$ (Figure 1). Eastern sampling locations include three colonies: Kopački rit, Čepin and Mrsunjski Lug. Čepin is a small colony with 46 pairs, Mrsunjski Lug is a medium colony with 148 pairs, while Kopački rit is a large colony with 424 pairs (KomLjenović 2019). Their environment and climate are influenced by three major rivers - Danube, Drava and Sava. Danube and Drava construct major floodplains and wetlands, also known as the Kopački rit Nature Park (Sić 1975, Blagojević 2008). Central sampling locations include Kravarsko, Piljenice and Slovinci. Kravarsko and Slovinci are medium colonies with 55 and 64 pairs, respectively. Piljenice is a large colony with 325 breeding pairs (Komljenović 2019). Central Croatia is heavily influenced by Sava tributaries: Sutla, Una, Kupa, Sunja, Lonja, Češma and Ilova, as well as by Drava tributaries: Plitvica, Bednja, Gliboki potok, Mura and Trnava (CRkvenčıć 1974). The primary and secondary flight feathers were collected from adult birds either as shed feathers or from dead individuals found under the colony. The feathers had been stored in paper envelopes before the analysis. The feathers were analysed for the following elements: lead ( $\mathrm{Pb})$, arsenic (As), cadmium (Cd), and selenium (Se). Prior to the analysis, all the feather samples had been washed with deionized water and ground to fine powder using a heavy-metal-free mill, following digestion with a $10 \mathrm{~mL}$ 5:1 mixture of $\mathrm{HNO}_{3}$ (Trace metal grade, Fischer) and $\mathrm{H}_{2} \mathrm{O}_{2}$ (Primar-trace metal grade, Fischer) in a microwave oven (CEM Mars 6, USA). The concentrations of metals and metalloids were measured using ICP-MS (Agilent 7500a Inductively Coupled Plasma Mass Spectrometer). All the feather samples were measured in duplicate with Chicken - Trace elements NCS ZC 73016 as reference material. The limit of detection for the analysed elements is as follows: $0.02 \mu \mathrm{g} \mathrm{kg}^{-1}$ for lead, $0.04 \mu \mathrm{g} \mathrm{kg}^{-1}$ for arsenic, $0.0004067 \mu \mathrm{g} \mathrm{kg}^{-1}$ for cadmium, and $0.06563 \mu \mathrm{g} \mathrm{kg}^{-1}$ for selenium. All the analyses were conducted at the Faculty of Agrobiotechnical Sciences in Osijek, Croatia. Table 1 shows the concentrations for each sample, as well as the arithmetic mean ( $\mu \mathrm{g} \mathrm{kg}^{-1} \mathrm{dry}$ weight $) \pm S D$ for each location. Figures 2-5 show the data by boxplots (the line in the middle of the box representing the median, the box representing the minimum and the maximum value). 


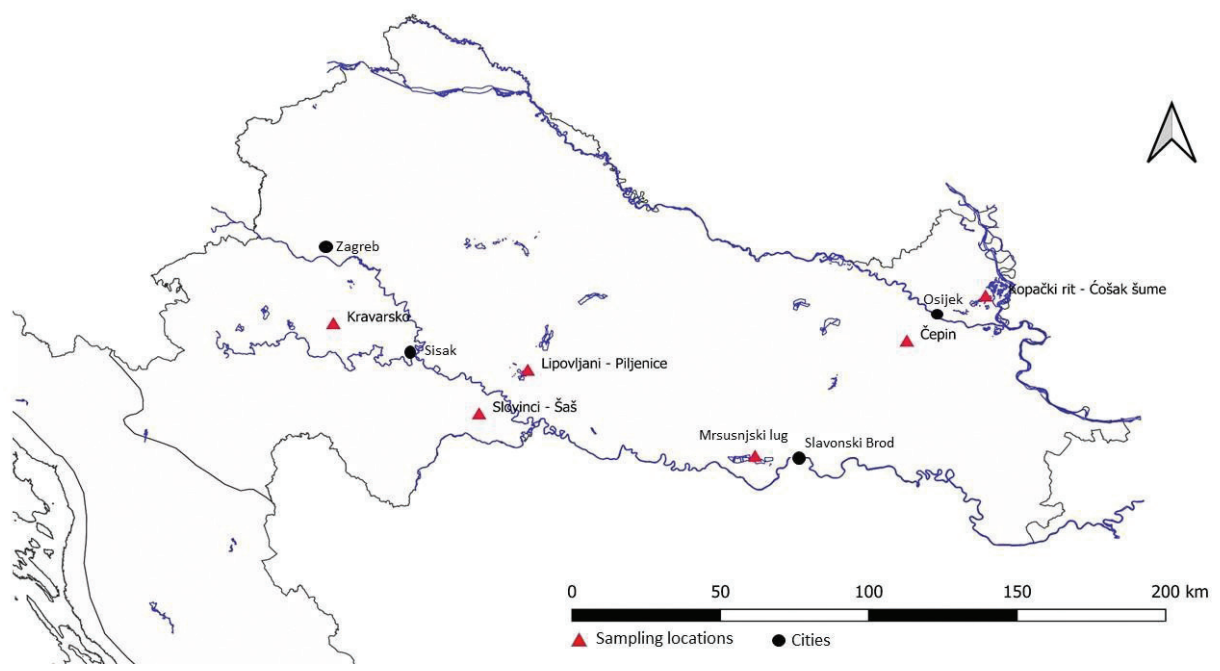

Figure 1. The sampling locations, marked as red triangles, of the Grey Heron feathers in Croatia.

Slika 1. Lokaliteti, označeni crvenim trokutom, na kojima su prikupljena pera sivih čaplji u Hrvatskoj.

\section{RESULTS AND DISCUSSION}

Feather analysis has many advantages. i.e. it is easy to collect a sufficient amount of samples and to store the samples; the metal and metalloid concentrations reflect internal concentration during feather growth due to dietary intake, or they can pinpoint local contamination (JASPERS et al. 2019). Furthermore, metal and metalloid concentrations in the feathers represent long-term contamination processes. When interpreting the results, it is important to take into account external contamination, e.g. atmospheric dust, water or contaminant deposition during preening, and geochemical data (Borghesi et al. 2017). Lead, arsenic, cadmium and selenium were detected in all the measured feather samples.

The highest lead concentration was observed in Slovinci $(2194.53 \pm 416.20 \mu \mathrm{g}$ $\mathrm{kg}^{-1} \mathrm{dw}$ ). Surprisingly, a relatively high concentration of lead was observed in Kopački rit as well $\left(1955.85 \pm 1373.07 \mu \mathrm{g} \mathrm{kg}^{-1} \mathrm{dw}\right)$. All the measured concentrations were below the toxicity level. Adverse effects in birds occur at levels of 4000 $\mu \mathrm{g} \mathrm{kg}{ }^{-1}$ of lead in feathers (Custer \& Hoffman 1994, Tsipoura et al. 2011, Burger 2013). Lowest lead concentration was measured in Piljenice (587.77 $\pm 330.18 \mu \mathrm{g}$ $\mathrm{kg}^{-1} \mathrm{dw}$ ) (Table 1; Figure 2). 


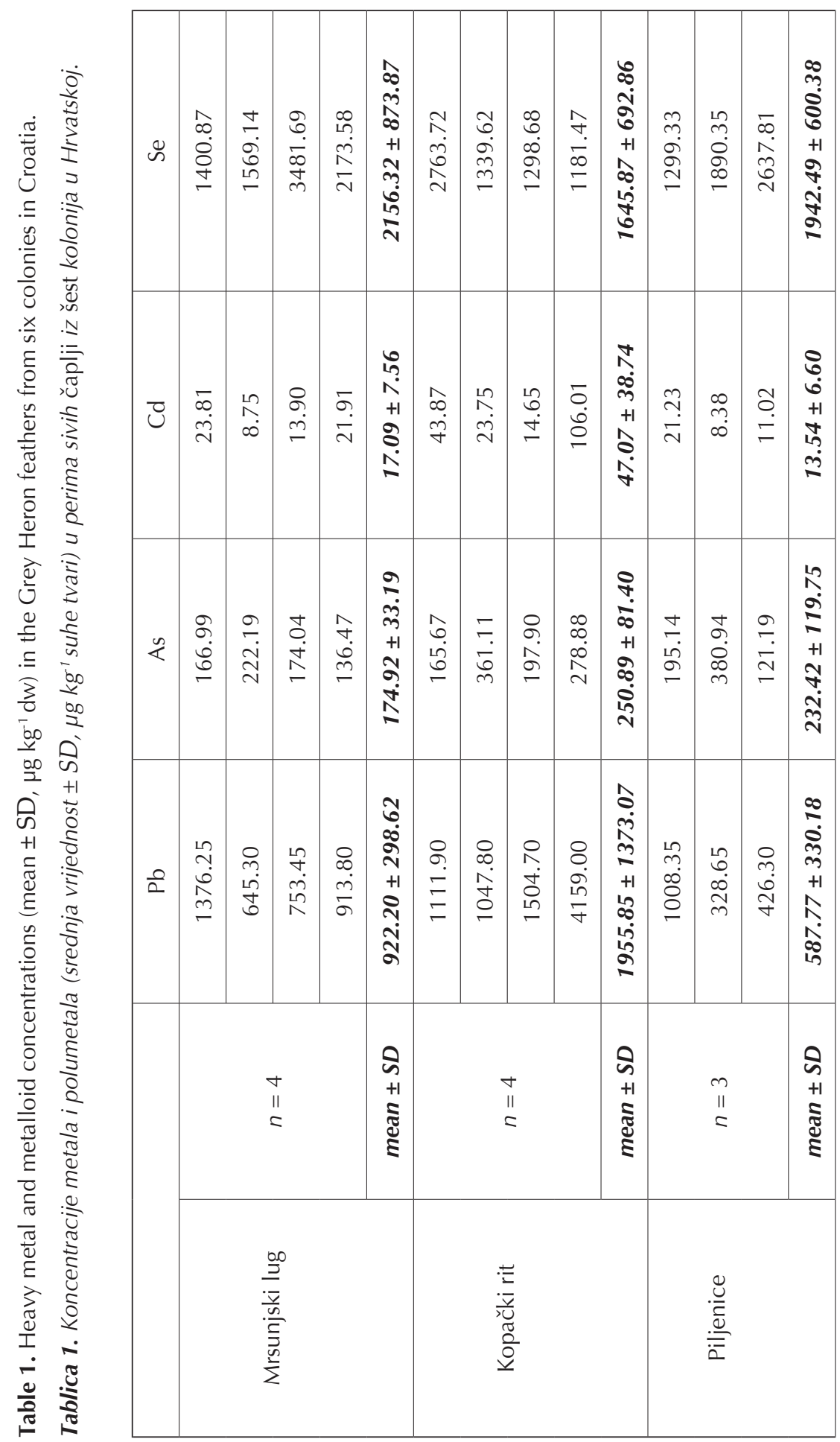




\begin{tabular}{|c|c|c|c|c|c|c|c|c|c|c|}
\hline$\stackrel{\oplus}{ }$ & 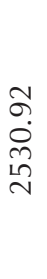 & $\begin{array}{l}\stackrel{N}{N} \\
\stackrel{\sim}{+} \\
\end{array}$ & $\begin{array}{l}\sigma \\
\leftarrow 0 \\
\infty \\
-\end{array}$ & 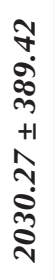 & 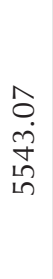 & $\begin{array}{l}\text { Ln } \\
\leftarrow \\
\infty \\
\stackrel{0}{0} \\
\stackrel{-}{-}\end{array}$ & 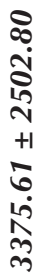 & $\begin{array}{l}\mathcal{V} \\
\dot{0} \\
\infty \\
0 \\
-\end{array}$ & 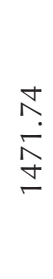 & 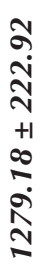 \\
\hline ర & $\underset{\sigma}{\sigma}$ & $\begin{array}{l}\stackrel{+}{\sim} \\
\infty \\
\infty\end{array}$ & $\begin{array}{l}\bar{\infty} \\
\stackrel{\sim}{\wedge}\end{array}$ & 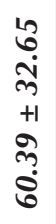 & $\begin{array}{l}\stackrel{2}{O} . \\
\stackrel{1}{\wedge}\end{array}$ & $\begin{array}{l}\stackrel{0}{ } \\
\infty \\
\infty\end{array}$ & 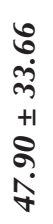 & $\underset{\infty}{\stackrel{\sigma}{+}}$ & 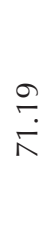 & $\begin{array}{l}\hat{m} \\
\text { के } \\
+1 \\
\text { के } \\
\text { के } \\
\text { शे }\end{array}$ \\
\hline$\sum^{\infty}$ & 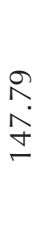 & $\begin{array}{l}\Re \\
0 \\
0\end{array}$ & $\begin{array}{l}\bar{\infty} \\
\stackrel{N}{N}\end{array}$ & 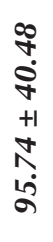 & 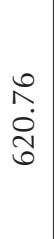 & $\begin{array}{l}\forall \\
\infty \\
\infty \\
\sigma\end{array}$ & 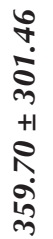 & $\begin{array}{l}\hat{\circ} \\
\stackrel{1}{0} \\
\stackrel{\circ}{-}\end{array}$ & $\begin{array}{l}\hat{\sigma} \\
\infty \\
\stackrel{0}{0}\end{array}$ & 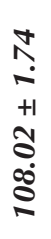 \\
\hline$\frac{0}{\alpha}$ & 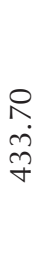 & $\begin{array}{l}\stackrel{\ominus}{n} \\
\text { ñ } \\
\stackrel{n}{\sim}\end{array}$ & 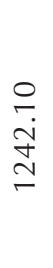 & 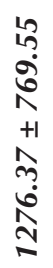 & 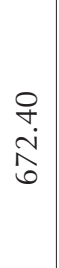 & $\begin{array}{l}\stackrel{0}{ } \\
\infty \\
\frac{\infty}{\sigma}\end{array}$ & 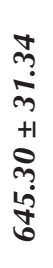 & 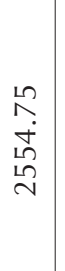 & $\begin{array}{l}\stackrel{\ominus}{m} \\
\stackrel{+}{+} \\
\infty \\
\infty \\
-\end{array}$ & 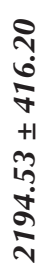 \\
\hline & & $\begin{array}{l}n \\
\| \\
=\end{array}$ & & 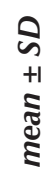 & & & $\begin{array}{l}\text { के } \\
+1 \\
\text { ฐँ } \\
\Xi\end{array}$ & 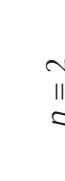 & & $\begin{array}{l}\text { ڤ } \\
+1 \\
\Xi \\
\Xi \\
\Xi\end{array}$ \\
\hline & & 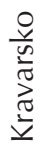 & & & $x$ & & & $\frac{\bar{y}}{\stackrel{\bar{J}}{\partial}}$ & & \\
\hline
\end{tabular}




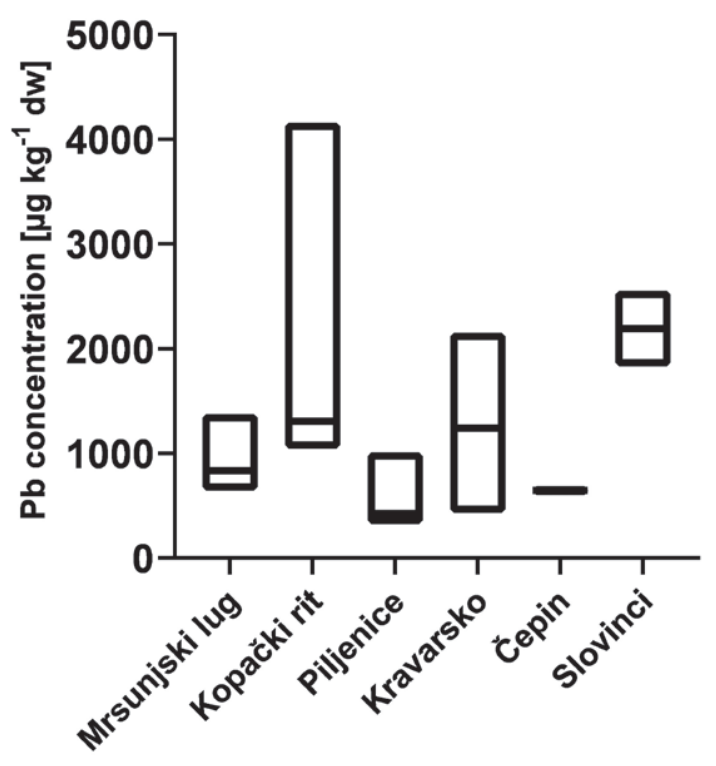

Figure 2. Boxplot of lead $(\mathrm{Pb})$ concentrations $\left(\mu \mathrm{g} \mathrm{kg}^{-1} \mathrm{dw}\right)$ in the Grey Heron feathers from six colonies in Croatia (median, min-max).

Slika 2. Koncentracija olova (Pb) ( $\mu \mathrm{g} \mathrm{kg}^{-1}$ suhe tvari) u perima sivih čaplji iz šest kolonija u Hrvatskoj (medijan, min-max).

Lead is widely distributed in the environment with the most relevant source being lead ammunition, causing lead poisoning especially in waterfowl, apex predators and scavengers (GARCíA-Fernández 2014). Lead accumulates primarily in bones and kidneys, and is greater in females, than in males and young birds (Koivula \& Eeva 2010). Lead in soil is mostly found by the course of the river Drava as a result of anthropogenic activities, as well as in alluvial plains, and the confluence of the rivers Drava and Danube (Halamić et al. 2009, Šajn et al. 2011, Halamić et al. 2012). From soil, lead can adsorb to sediment, and leach into rivers, affecting every trophic level (Millot et al. 2004). According to Goede \& De Bruin (1986), lead can be deposited in the preen gland secretion of the birds. After feather formation, the feather can give indirect information about exposure to lead. According to Grúz et al. (2019), the highest concentration in the feathers of predatory birds in Hungary was $2300 \mu \mathrm{g} \mathrm{kg}^{-1} \mathrm{dw}$, which does not indicate poisoning. Lead does not generally biomagnify through the food chain, therefore high lead levels may indicate proximity to contaminated sites or secondary poisoning through lead-poisoned prey or carcasses (LeE 2003, Legagneux et al. 2014, 
Ali \& Khan 2019, Grúz et al. 2019). Lead ammunition is widely used in hunting in Croatia and is causing acute and chronic lead poisoning, confirmed in scavenger species, as the Griffon Vulture (Gyps fulvus) (TišLjar et al. 2019).

The measured levels of arsenic ranged from $95.74 \pm 40.48 \mu \mathrm{g} \mathrm{kg}{ }^{-1} \mathrm{dw}$ in Kravarsko to $359.70 \pm 301.46 \mu \mathrm{g} \mathrm{kg}^{-1} \mathrm{dw}$ in Čepin (Table 1; Figure 3). All the measured levels were below the level of adverse biological effect of 2000-10,000 $\mu \mathrm{g} \mathrm{kg}^{-1} \mathrm{dw}$ (EISLER 1988).

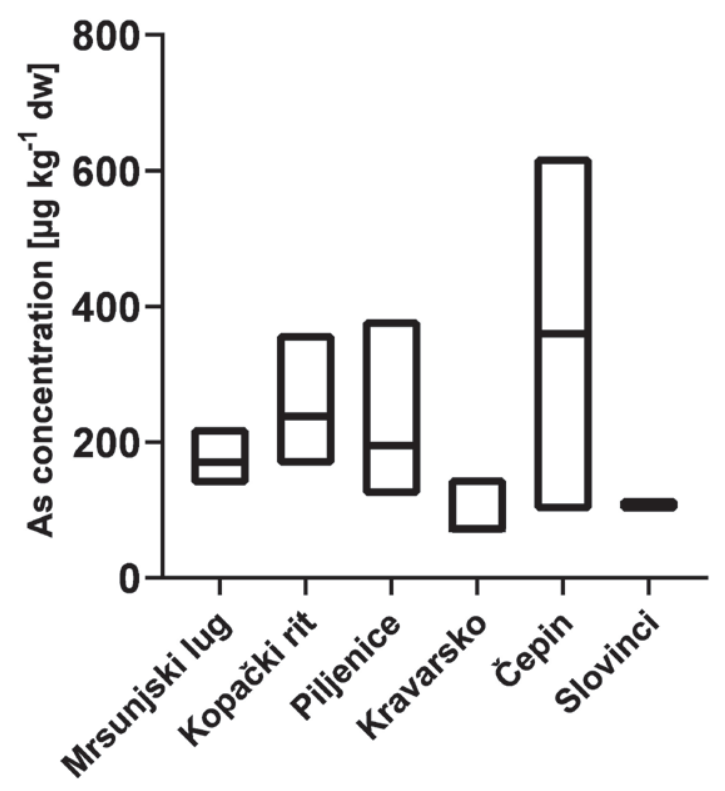

Figure 3. Boxplot of arsenic (As) concentrations $\left(\mu \mathrm{g} \mathrm{kg}{ }^{-1} \mathrm{dw}\right)$ in the Grey Heron feathers from six colonies in Croatia (median, min-max).

Slika 3. Koncentracija arsena (As) ( $\mu g \mathrm{~kg}^{-1}$ suhe tvari) u perima sivih čaplji iz šest kolonija u Hrvatskoj (medijan, min-max).

Arsenic has the ability to bioaccumulate, especially in its inorganic form, and it can affect reproduction (KoIvula \& Eeva 2010). Arsenic concentration in the feathers reflects environmental pollution well; however, it does not correspond with internal levels (GeEns et al. 2010). Arsenic concentration in severely polluted areas can be as high as 30,000 $\mu \mathrm{g} \mathrm{kg}^{-1}$ in passerine birds (JANSSENS et al. 2001). According to Sánchez-Virosta et al. (2015), arsenic concentrations are below 1000 $\mu \mathrm{g} \mathrm{kg}^{-1}$ in unpolluted areas, and below $10,000 \mu \mathrm{g} \mathrm{kg}^{-1}$ in polluted areas. The highest recorded arsenic level is $359.70 \mu \mathrm{g} \mathrm{kg}^{-1}$ (in Čepin), lower than the one mea- 
sured in Hungary of the bird of prey feathers ( $400 \mu \mathrm{g} \mathrm{kg}^{-1} \mathrm{dw}$ ) according to Grúz et al. (2019), suggesting relatively unpolluted sampling areas in Croatia. According to Luo et al. (2015) and EISLER (1988), arsenic is accumulated in the organisms, yet it does not biomagnify through the food chain. When compared to ecologically similar species in Table 2, the Cape Cormorant (Phalacrocorax capensis), the Lesser Flamingo (Phoeniconaias minor) and the Crested Ibis (Nipponia nippon) had considerably higher arsenic concentrations in their feathers. This may be due to different feeding habits, and the sampling locations were close to agricultural activities (e.g. pesticide, herbicide and fertilizer use are known as arsenic sources).

The highest recorded concentration of cadmium was $79.30 \pm 9.37 \mu \mathrm{g} \mathrm{kg}^{-1} \mathrm{dw}$ in the Slovinci colony (Table 2, Figure 4). In all the colonies, cadmium levels were considerably lower than the adverse biological effect level of $2000 \mu \mathrm{g} \mathrm{kg}^{-1}$ (EIsLER 1985), with the lowest measured concentration in Piljenice (13.54 $\left.\pm 6.60 \mathrm{\mu g} \mathrm{kg}^{-1} \mathrm{dw}\right)$.

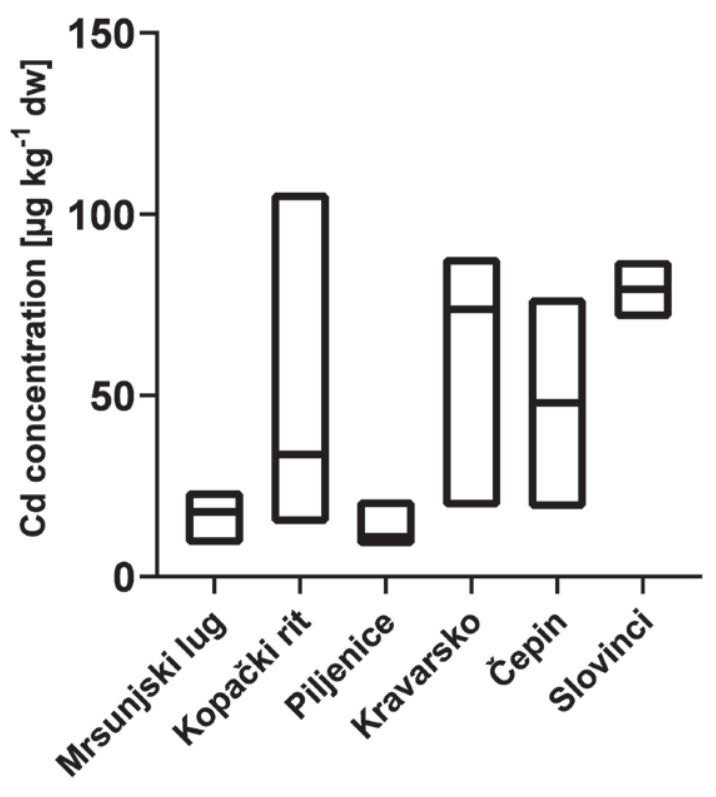

Figure 4. Boxplot of cadmium (Cd) concentrations $\left(\mu \mathrm{g} \mathrm{kg} \mathrm{g}^{-1} \mathrm{dw}\right)$ in the Grey Heron feathers from six colonies in Croatia (median, min-max).

Slika 4. Koncentracija kadmija (Cd) ( $\mu g \mathrm{~kg}^{-1}$ suhe tvari) u perima sivih čaplji iz šest kolonija u Hrvatskoj (medijan, min-max). 


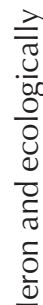

\begin{tabular}{|c|c|c|c|c|c|c|c|}
\hline 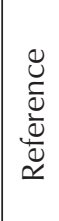 & $\begin{array}{l}\vec{\lambda} \\
\frac{0}{2} \\
\frac{n}{n} \\
\frac{n}{E}\end{array}$ & 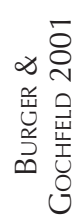 & 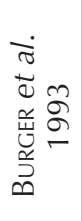 & 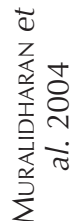 & 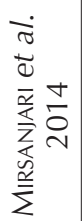 & 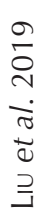 & 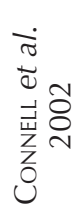 \\
\hline
\end{tabular}

일

殅 $\frac{\dot{n}}{0} \cdot \frac{1}{0}$

入े

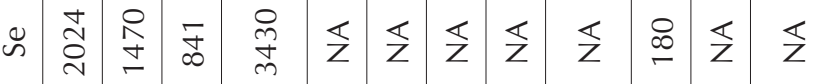

$\cup \bar{\sigma}^{\circ}$

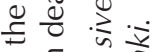

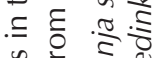

c.

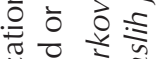

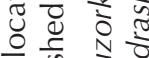

으 등

डิ

\& $\stackrel{0}{ \pm}$

원 은

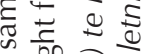

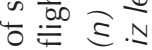

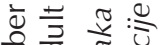

ఏ ฮ

)

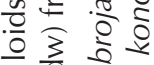

䨌

己

o

흔 है है

$\frac{\pi}{2} \frac{0}{2}$

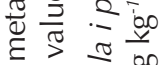

>월

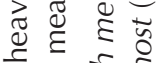

प

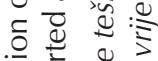

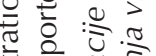

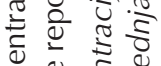

ये

ริ

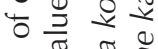

ㄷำ $\frac{\pi}{0}$

制

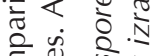

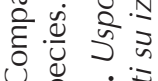

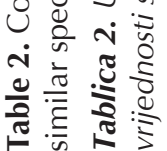

\&

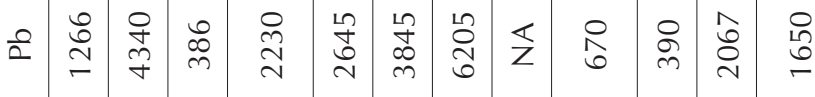

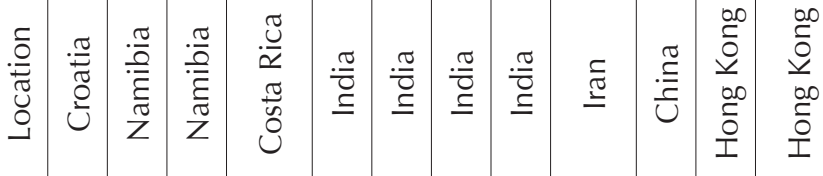

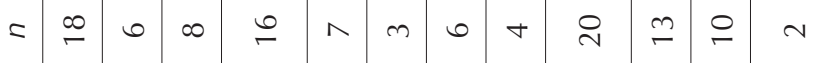

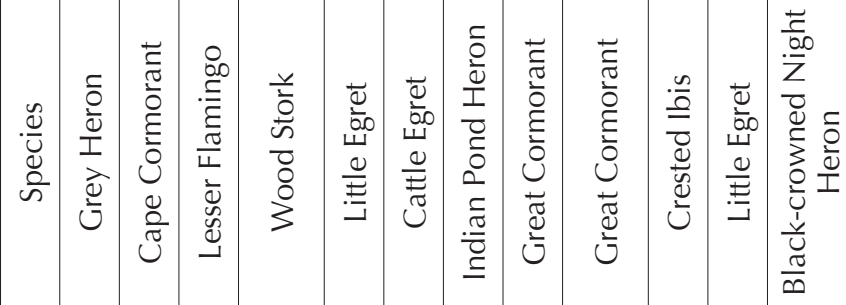

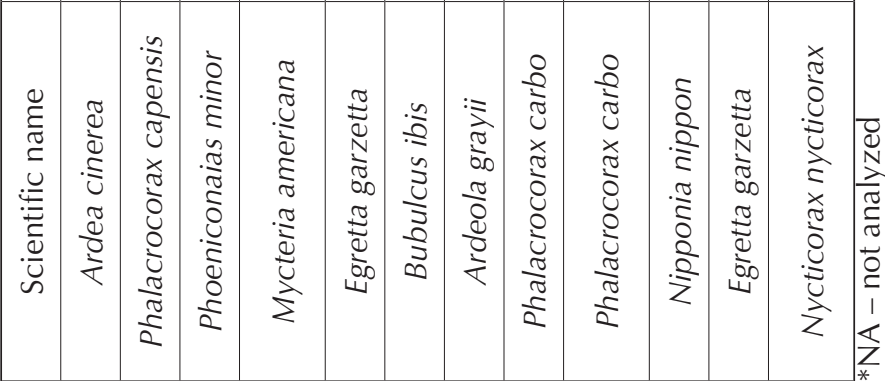


Birds are exposed to cadmium primarily throughout their diets, and the levels are influenced by their feeding habits, age, physiological status, etc. Chronic exposure to cadmium reduces reproductive success (GARCíA-Fernández 2014). Uneven cadmium distribution on the Croatian soil is reported by Halamić et al. (2009), as well as in the Podravina region. Higher cadmium concentrations in the air were reported in the flood plain sediments of the rivers Drava and Mura according to VučKović et al. (2012). Higher cadmium content in Croatia is attributed to the mining activities in Slovenia (Mezica $\mathrm{Pb}-\mathrm{Zn}$ mine) and Austria ( $\mathrm{Pb}-\mathrm{Zn}$ mine with $\mathrm{Cd}$ ) (Šajn et al. 2011). However, cadmium concentrations measured in the Grey Heron feathers were rather low on all locations when compared to the levels measured in the Eurasian Oystercatcher (Haematopus ostralegus) of $180 \mathrm{\mu g} \mathrm{kg}^{-1}$ from the Wadden Sea (Sтоск et al. 1989), and the birds of prey in Hungary, with the recorded concentration of $200 \mu \mathrm{g} \mathrm{kg}^{-1} \mathrm{dw}$ (GRÚz et al. 2019). In polluted areas, cadmium levels may rise up to $200 \mu \mathrm{g} \mathrm{kg}^{-1} \mathrm{dw}$, measured in the feathers of the Great Tit (Parus major) (DAuwe et al. 2004), suggesting a relatively unpolluted environment in Croatia.

Selenium in the flight feathers of Grey Herons ranged from $127.18 \pm 222.92 \mu \mathrm{g}$ $\mathrm{kg}^{-1} \mathrm{dw}$ in Slovinci to $3375.61 \pm 2502.80 \mu \mathrm{g} \mathrm{kg}^{-1} \mathrm{dw}$ in Čepin (Table 1, Figure 5). All the measured concentrations were below the levels that may cause adverse health effects (3800 $\left.\mu \mathrm{g} \mathrm{kg}^{-1} \mathrm{dw}\right)$ (BURger 2013).

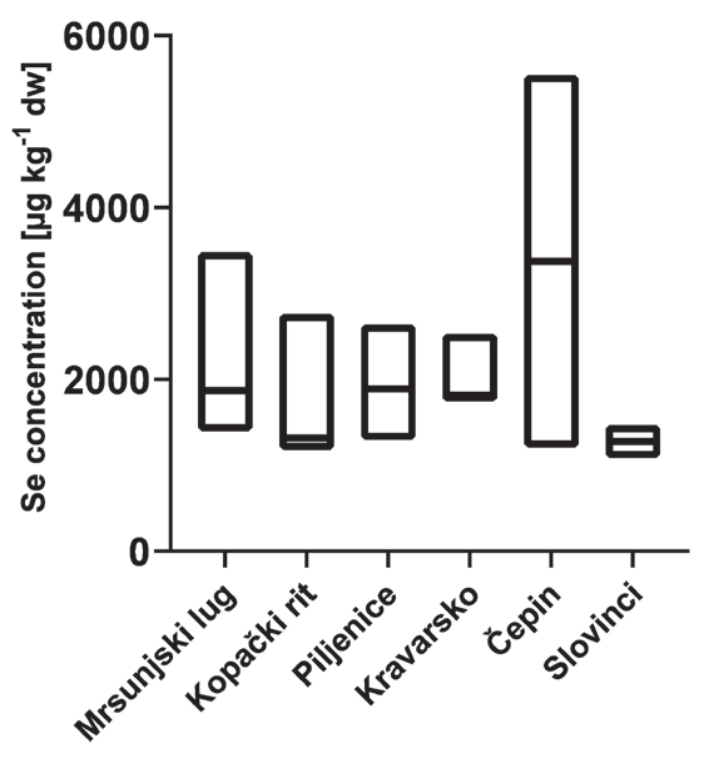

Figure 5. Boxplot of selenium (Se) concentrations $\left(\mu \mathrm{g} \mathrm{kg}{ }^{-1} \mathrm{dw}\right.$ ) in the Grey Heron feathers from six colonies in Croatia (median, min-max).

Slika 5. Koncentracija selena (Se) ( $\mu \mathrm{g} \mathrm{kg}^{-1}$ suhe tvari) u perima sivih čaplji iz šest kolonija u Hrvatskoj (medijan, min-max). 
Selenium plays a biological role in birds; however, it is very embryotoxic at high levels, causing developmental abnormalities with visible malformations in embryos and chicks (García-Fernández 2014). Goede \& De Bruin (1986) report that selenium contamination source is external, that it comes mostly from the preen gland secretions, and increases considerably in the course of time. Selenium may cause toxicity in the range $3800-26,000 \mu \mathrm{g} \mathrm{kg}^{-1}$ (Burger 2013). According to HeInz (1996), selenium levels of $1800 \mathrm{\mu g} \mathrm{kg}^{-1}$ may cause sub-lethal adverse effects. Selenium is known to accumulate in the aquatic food chain (MAIER et al. 1998). Nevertheless, our results indicate relatively unpolluted continental regions in Croatia.

The basic assumption is that Grey Herons get exposed to heavy metals and metalloids through their diet and food source. While the fish fauna of Sava, Drava and Danube is relatively well known (MraKovčić et al. 2006), and heavy metals and metalloids were identified as pollutants in the Danube river and its tributaries (LÁszLó 2014, ICPDR 2015), there is only one study on biomonitoring heavy metals in fish in the Croatian part of Danube (ZRNČić et al. 2012). The contamination of lead and cadmium in fish from Danube was analysed, and there was significant difference of the mean concentrations of the measured values according to feeding habits (ZRNČić et al. 2012). According to ZRNčić et al. (2012), lead ranged from $0.015 \mu \mathrm{g}^{-1} \mathrm{dw}$ in planktivorous to $0.039 \mu \mathrm{g}^{-1} \mathrm{dw}$ in herbivorous fish, and cadmium from $0.013 \mu \mathrm{g}^{-1} \mathrm{dw}$ in herbivorous to $0.018 \mu \mathrm{g}^{-1} \mathrm{dw}$ in piscivorous fish. All of these concentrations were below the national and EU-permitted levels.

As shown in Table 2, only a minor number of studies assessed metal concentration in the flight feathers in adult similar bird species. When compared with the results of other studies, our preliminary data indicate relatively low metal and metalloid content in Grey Herons. However, the source of the metals deposited in the feather cannot be determined. According to Fu et al. (2013), the flight feathers of cranes and herons from a polluted province in China had higher levels of lead, arsenic and cadmium than herons from Croatia. Ansara-Ross et al. (2013) also reported higher levels of arsenic and lead, cadmium levels are similar, and selenium levels are lower in the primary feathers of the African Grass-owl (Tyto capensis).

Preliminary results of this study indicate that the average levels of lead, arsenic and cadmium are well below the toxic levels for all sampled locations. Taking this into account, we conclude that reported values show relatively low metal and metalloid content in Continental Croatia. However, considering scarce data on the Grey Heron post-breeding dispersion and unknown heavy metal and metalloid sources, we can only assume low environmental pollution. Our study contains preliminary results suggesting further investigation is needed on a larger sample size, as well as an establishment of continuous pollutant biomonitoring of predatory bird species in Croatia. 


\section{References}

Ali, H., KHAN, E. (2019): Trophic transfer, bioaccumulation, and biomagnification of nonessential hazardous heavy metals and metalloids in food chains/webs-Concepts and implications for wildlife and human health. Human and Ecological Risk Assessment 25(6): 1353-1376.

Ansara-Ross, T. M., Ross, M. J., Wepener, V. (2013): The use of feathers in monitoring bioaccumulation of metals and metalloids in the South African endangered African grass-owl (Tyto capensis). Ecotoxicology 22(6): 1072-1083.

BirdLife International (2020): Species factsheet: Ardea cinerea. Downloaded from http:// www.birdlife.org on 24/09/2020

Blagojević, A. (2008): Zemljopisno, povijesno, upravno i pravno određenje istočne Hrvatske-korijeni suvremenog regionalizma. Collected papers of the Law Faculty of the University of Rijeka 29: 1149 - 1180.

Blasco-Zumeta, J., Heinze, G.M. (2020): Identification Atlas of Aragorn Birds. Grey Heron. Downloaded from: http://blascozumeta.com/wp-content/uploads/aragonbirds/non-passeriformes/043.greyheron-acinerea.pdf on 24.9.2020.

Borghesi, F., Dinelli, E., Migani, F., Bechet, A., Rendón-Martos, M., Amat, J. A., SomMer, S. Gillingham, M. A. (2017): Assessing environmental pollution in birds: a new methodological approach for interpreting bioaccumulation of trace elements in feather shafts using geochemical sediment data. Methods in Ecology and Evolution 8(1): 96-108.

Burger, J. (1993): Metals in avian feathers: Bioindicators of environmental pollution. Reviews of Environmental Contamination and Toxicology 5: 197 - 306.

BURGER, J. (1994): Metals in avian feathers: bioindicators of environmental pollution. Reviews of Environmental Temporal trends (1989-2011) in levels of mercury and other heavy metals in feathers of fledgling great egrets nesting in Barnegat Bay, NJ. Environmental Research 122: 11-17.

Burger, J. (1995): Heavy metal and selenium levels in feathers of herring gulls (Larus argentatus). Differences due to years, gender, and age at Captree, Long Island. Environmental Monitoring and Assessment 38: 37-50.

Burger, J. (2013): Temporal trends (1989-2011): in levels of mercury and other heavy metals in feathers of fledgling great egrets nesting in Barnegat Bay, NJ. Environmental Research 122: 11-17.

Burger, J., EichHorst, B. (2005): Heavy metals and selenium in grebe eggs from Agassiz National Wildlife Refuge in northern Minnesota. Environmental Monitoring and Assessment 107: 285-295.

Burger, J., Gochfeld, M. (2001): Metal levels in feathers of cormorants, flamingos and gulls from the coast of Namibia in southern Africa. Environmental Monitoring and Assessment 69(2): 195-203.

Burger, J., Gochfeld, M., Sullivan, K., Irons, D. (2007): Mercury, arsenic, cadmium, chromium lead, and selenium in feathers of pigeon guillemots (Cepphus columba) from Prince William Sound and the Aleutian Islands of Alaska. Science of the Total Environment 387: 175-184. 
Burger, J., Rodgers, J. A., Gochfeld, M. (1993): Heavy metal and selenium levels in endangered wood storks Mycteria americana from nesting colonies in Florida and Costa Rica. Archives of Environmental Contamination and Toxicology 24(4): 417-420.

Connell, D. W., Wong, B.S. F., Lam, P.K. S., Poon, K.F., Lam, M. H. W., Wu, R. S. S., RichARDSON, B. J., YEN, Y. F. (2002): Risk to breeding success of Ardeids by contaminants in Hong Kong: evidence from trace metals in feathers. Ecotoxicology 11(1): 49-59.

Crkvenčić I., Dugački Z., Jelen I., Kurtek P., Malić A., Šašek M. (1974): Geografija SR Hrvatske. Središnja Hrvatska 2. Školska knjiga, Zagreb.

Custer, T. W., Hoffman, W. L. (1994): Trace elements in canvasback (Aytha valisineria) wintering in Louisiana, USA, 1987 - 1988. Environmental Pollution 84: 253-259.

Daume, T., Janssens, E., Bervoets, L., Blust, R., Eens, M. (2004): Relationships between metal concentrations in great tit nestlings and their environment and food. Environmental Pollution 131(3): 373-380.

del Hoyo, J. D., Elliott, A., Sargatal, J., Christie, D. (1992): Handbook of the Birds of the World Vol. 1. Lynx Edicions/Birdlife International.

Deng H, Zhang Z, Chang C, Wang Y (2007): Trace metal concentration in great tit (Parus major) and Greenfinch (Carduelis sinica) at the Western Mountains of Beijing, China. Environmental Pollution 148: 620-626.

EISLER, R. (1985): Cadmium Hazards to Fish, Wildlife, and Invertebrates: A Synopsis Review. US Fish and Wildlife Service.

EIsLER, R. (1988): Arsenic hazards to fish, wildlife, and invertebrates: a synoptic review. US Fish and Wildlife Service.

Eulaers, I., Covaci, A., Herzke, D., Eens, M., Sonne, C., Moum, T., Schnug, L., HansSen, S. A., Johnsen, T. V., Bustnes, J. O., Jaspers, V. L. (2011): A first evaluation of the usefulness of feathers of nestling predatory birds for non-destructive biomonitoring of persistent organic pollutants. Environment International 37(3): 622-630.

Fransson, T., Kolehmainen, T., Kroon, C., Jansson, L. \& Wenninger, T. (2010): EURING list of longevity records for European birds. https:/euring.org/data-and-codes/ longevity-list

Fu, J., WAnG, Q., Wang, H., Yu, H., Zhang, X. (2014): Monitoring of non-destructive sampling strategies to assess the exposure of avian species in Jiangsu Province, China to heavy metals. Environmental Science and Pollution Research 21(4): 2898-2906.

García-Fernández, A. J. (2014): Ecotoxicology, avian. pp. 289-294. In: Wexler, P. (ed.): Encyclopedia of Toxicology, Elsevier Inc., Academic Press.

Geens, A., Dauwe, T., Bervoets, L., Blust, R., Eens, M. (2010): Haematological status of wintering great tits (Parus major) along a metal pollution gradient. Science of the Total Environment 408(5): 1174-1179.

Goede, A. A. (1985): Mercury, selenium, arsenic and zinc in waders from the Dutch Wadden Sea. Environmental Pollution Series A 37: 287-309.

Goede, A. A., De Bruin, M. (1984): The use of bird feather parts as a monitor for metal pollution. Environmental Pollution Series B, Chemical and Physical 8(4): 281-298.

Goede, A. A., De Bruin, M. (1986): The use of bird feathers for indicating heavy metal pollution. Environmental monitoring and assessment 7(3): 249-256. 
Grúz, A., Mackle, O., Bartha, A., Szabó, R., Déri, J., Budai, P., Lehel, J. (2019): Biomonitoring of toxic metals in feathers of predatory birds from eastern regions of Hungary. Environmental Science and Pollution Research 26(25): 26324-26331.

Halamić, J., Peh, Z., Miкo, S., Galović, L., Šorša, A. (2009): Geochemical atlas of the Republic of Croatia. Croatian Geological Survey, Zagreb 40-68.

Halamić, J., Peh, Z., Miкo, S., Galović, L., Šorša, A. (2012): Geochemical atlas of Croatia: environmental implications and geodynamical thread. Journal of Geochemical Exploration 115: 36-46.

Hancock, J., Kushlan, J. (1984): The Herons Handbook. Croom Helm. London \& Sydney.

Heinz, G. H. (1996): Selenium in birds. Environmental contaminants in wildlife: interpreting tissue concentrations. LeWIS, Boca Raton 447-458.

Horai, S., Watanabe, I., Takada, H., Imamizu, Y., Hayashi, T., Tanabe, S., Kuno, K. (2007): Trace element accumulations in 13 avian species collected from the Kanto area, Japan. Science of the Total Environment 373: 512-525.

ICPDR (2015): Joint Danube Survey 3. A Comprehensive Analysis of Danube Water Quality. International Commission for the Protection of the Danube River. Vienna.

Jakubas, D., Mioduszewska, A. (2005): Diet composition and food consumption of the grey heron (Ardea cinerea) from breeding colonies in northern Poland. European Journal of Wildlife Research 51: 191-198.

Janssens, E., Daune, T., Bervoets, L., Eens, M. (2001): Heavy metals and selenium in feathers of great tits (Parus major) along a pollution gradient. Environmental Toxicology and Chemistry 20(12): 2815-2820.

Jaspers, V. L., Covaci, A., Herzke, D., Eulaers, I., Eens, M. (2019): Bird feathers as a biomonitor for environmental pollutants: prospects and pitfalls. Trends in Analytical Chemistry 118: 223-226.

Korvula, M. J., Eeva, T. (2010): Metal-related oxidative stress in birds. Environmental Pollution 158(7): 2359-2370.

Komljenović, J. (2019): Breeding of the Grey Heron (Ardea cinerea LINNAEUS, 1758) in Croatia in 2019. (Master's thesis, Odjel za biologiju, Sveučilište Josipa Jurja Strossmayera u Osijeku)

Kralj, J., Barišić, S., Tutiš, V., Ćíović, D. (2013): Atlas selidbe ptica Hrvatske. HAZU, Zagreb.

Kushlan, J. (1993): Colonial Waterbirds as Bioindicators of Environmental Change. Colonial Waterbirds 16(2): 223-251.

LÁszló, F. (2014): Pollution by Heavy Metals in the Danube River Basin. The Danube River Basin. The Handbook of Environmental Chemistry. Springer-Verlag Berlin Heidelberg 39: 85-93.

LEE, D. P. (2003): Lead and cadmium accumulation levels in Korean raptors. Korean Journal of Ornithology 10(2): 103-108.

Legagneux, P., Suffice, P., Messier, J. S., Lelievre, F., Tremblay, J. A., Maisonneuve, C., SAINT-Louis, R., BÊTY, J. (2014): High risk of lead contamination for scavengers in an area with high moose hunting success. PLOS One 9: e111546. 
LiU, Q., Chen, Y., Maltby, L., Zheng, Y. and Ma, Q., (2019): Trace elements exposure of endangered crested ibis (Nipponia nippon) under in situ and ex situ conservations. Environmental Pollution 253: 800-810.

LukAč, G. (2007): Popis ptica Hrvatske. Natura Croatica 16(1): 1-148.

LuO, J., YE, Y., YIN, X. (2015): Bioaccumulation and dietary exposure of the red-crowned cranes (Grus japonensis) to arsenic in Zhalong wetland, northeastern China. Aquatic Ecosystem Health \& Management 18(1): 121-129.

Maier, K. J., Nelson, C. R., Bailey, F. C., Klaine, S. J., Knight, A. W. (1998): Accumulation of selenium by the aquatic biota of a watershed treated with seleniferous fertilizer. Bulletin of Environmental Contamination and Toxicology 60(3): 409-416.

Malik, R. N., ZEB, N. (2009): Assessment of environmental contamination using feathers of Bubulcus ibis L., as a biomonitor of heavy metal pollution, Pakistan. Ecotoxicology 18(5): 522-536.

Markowski, M., Kaliński, A., Skwarska, J., Wawrzyniak, J., Bańbura, M., Markowski, J., Zieliński, P. and BAŃBURA, J. (2013): Avian feathers as bioindicators of the exposure to heavy metal contamination of food. Bulletin of Environmental Contamination and Toxicology 91(3): 302-305.

MikušKa, J., Bogdanović, T., MikušKa, T., MikušKA, A., Šalić, V. (2005): Size and distribution of breeding colonies of Grey Heron Ardea cinerea in lowland Croatia. Acrocephalus 26: 37-40.

Millot, R., Allègre, C. J., Gaillardet, J., Roy, S. (2004): Lead isotopic systematics of major river sediments: a new estimate of the $\mathrm{Pb}$ isotopic composition of the Upper Continental Crust. Chemical Geology 203(1-2): 75-90.

Mirsanjari, M. M., Sheybanifar, F., Arjmand, F. (2014): The study of forest hara biosphere reserve in coast of persian gulf and the importance of heavy metal accumulation; case study: feathers of great cormorant. Nusantara Bioscience 6(2).

Mrakovčić, M., Brigić, A., Buj, I., Ćaleta, M., Mustafić, P. i Zanella, D. (2006): Crvena knjiga slatkovodnih riba Hrvatske. Ministarstvo kulture i Državni zavod za zaštitu prirode, Zagreb.

Muralidharan, S., Jayakumar, R., Vishnu, G. (2004): Heavy metals in feathers of six species of birds in the district Nilgiris, India. Bulletin of Environmental Contamination and Toxicology 73(2): 285-291.

Pilastro, A., Congiu, L., Tallandini, L., Turchetto, M. (1993): The use of bird feathers for the monitoring of cadmium pollution. Archives of Environmental Contamination and Toxicology 24(3): 355-358.

Rutkowska, M., P£otka-Wasylka, J., Lubinska-Szczygę, M., Różańska, A., MożejkoCiesielska, J., NAmieśnik, J. (2018): Birds' feathers-suitable samples for determination of environmental pollutants. Trends in Analytical Chemistry 109: 97-115.

Sánchez-Virosta, P., Espín, S., García-Fernández, A. J., Eeva, T. (2015): A review on exposure and effects of arsenic in passerine birds. Science of The Total Environment 512: 506-525.

Scheifler, R., Ceeurdassier, M., Morilhat, C., Bernard, N., Faivre, B., Flicoteaux, P., Giraudoux, P., Noël, M., Piotte, P., Rieffel, D., De Vaufleury, A., Badot, P. M. 
(2006): Lead concentrations in feathers and blood of common blackbirds (Turdus merula) and in earthworms inhabiting unpolluted and moderately polluted urban areas. Science of the Total Environment 371: 197-205.

Sić, M. (1975): Regionalna podjela Istočne Hrvatske. pp: 123-125. In: Cvitanović, A. (ed.): Geografija SR Hrvatske 3. Školska knjiga, Zagreb.

Stock, M., Herber, R. F. M., Geron, H. M. A. (1989): Cadmium levels in oystercatcher Haematopus ostralegus from the German Wadden Sea. Marine Ecology Progress Series 53: 227-34.

Stresemann, E., Stresemann, V. (1966): Die Mauser der Vögel. The Journal of Ornithology 107: 401-404.

Šajn, R., Halamić, J., Peh, Z., Galović, L., \& Alijagić, J. (2011): Assessment of the natural and anthropogenic sources of chemical elements in alluvial soils from the Drava River using multivariate statistical methods. Journal of Geochemical Exploration, 110(3): 278-289.

Tišljar, M., Modrić, M., Capak, H., Brzica, S., Krivohlavek, A., Šimpraga, B., Krstulović, F., Šerić Jelaska, L., Bakulić, L., Savić, V., Beck, R., Lucić, V., Severin, K. (2019): Pathomorphological investigation and the causes of deaths in 2018 -2019. as a step in protection and conservation of Griffon Vultures (Gyps fulvus) population in Croatia. In: The European Vulture Conference 2019 Tuesday 1 to Friday 4 October 2019 Algarve, Portugal.

Tsipoura, N., Burger, J., Newhouse, M., Jeitner, C., Gochfeld, M., Mizrahi, D. (2011): Lead, mercury, cadmium, chromium, and arsenic levels in eggs, feathers, and tissues of Canada geese of the New Jersey Meadowlands. Environmental Research 111(6): 775-784.

VučKović, I., Špirić, Z., StAFILOV, T., KušAn, V. (2012): Atmospheric deposition of cadmium in Croatia studied by using moss biomonitoring technique and ICP-AES. Geologica Macedonica 26(1): 11-19.

Witherby, H. F., Jourdain, F. C. R., Ticehurst, N. F., Tucker, B. W. (1949): The handbook of British birds. Witherby, London.

Zrnčić, S., Oraić, D., Ćaleta, M., Mihaljević, Ž., Zanella, D., Bilandžić, N. (2012): Biomonitoring of heavy metals in fish from the Danube River. Environmental Monitoring and Assessment 185(2): 1189-1198. 


\section{SAŽETAK}

Antropogenim aktivnostima povećava se razina metala i polumetala u okolišu rezultirajući njihovim zagađenjem. Mjerenje teških metala i polumetala neinvazivnim metodama dobar je pokazatelj stanja okoliša. U radu su predstavljeni rezultati prve analize teških metala: olova i kadmija te dva metaloida: arsena i selena u perju sivih čaplji Ardea cinerea koje se gnijezde u Hrvatskoj. Uzorkovanje pera sivih čaplji provedeno je tijekom sezone gniježđenja, u travnju i svibnju 2019. iz šest hrvatskih kolonija (Mrsunjski lug, Kopački rit, Piljenice, Kravarsko, Čepin i Slovinci). Primarna i sekundarna letna pera odraslih ptica prikupljena su ispod kolonija. Najveće koncentracije olova $(\mathrm{Pb})$ zabilježene su u perju iz Slovinaca $\left(2194,53 \pm 416,20 \mu \mathrm{g} \mathrm{kg}^{-1}\right.$ suhe tvari) i Kopačkog rita $\left(1955,85 \pm 1373,07 \mu \mathrm{g} \mathrm{kg}{ }^{-1}\right.$ suhe tvari). U Čepinu su izmjerene najviše koncentracije arsena (As; 359,70 $\pm 301,46 \mu \mathrm{g} \mathrm{kg}^{-1}$ suhe tvari) i selena (Se; 3375,61 $\pm 2502,80 \mu \mathrm{g} \mathrm{kg}^{-1}$ suhe tvari), a najviša razina kadmija (Cd) izmjerena je u koloniji Slovinci $\left(79,30 \pm 9,37 \mathrm{\mu g} \mathrm{kg}^{-1}\right.$ suhe tvari). Sve izmjerene razine metala i polumetala su ispod koncentracija koje se smatraju toksičnima za ptice. Preliminarni rezultati ovog istraživanja ukazuju na relativno nisku zagađenost okoliša kontinentalne Hrvatske, no potrebna su dodatna istraživanja i uspostava kontinuiranog praćenja metala i polumetala u okolišu te njihov utjecaj na vršne predatore. 